\title{
THE STATUS OF THE TRADE-ENVIRONMENT- SUSTAINABLE DEVELOPMENT TRIAD IN THE DOHA ROUND NEGOTIATIONS AND IN RECENT U.S. TRADE POLICY
}

\author{
Kevin C. Kennedy*
}

\section{INTRODUCTION}

Making environmental protection and sustainable development an integral part of international trade is not simply a bilateral issue. Rather, achieving the goals of environmental protection and sustainable development requires multilateral and regional approaches and solutions. Consequently, the work of intergovernmental organizations, most importantly the World Trade Organization (WTO) and the United Nations Environment Program, is crucial to the smooth functioning and proper integration of the interrelationship among trade, environment, and sustainable development. Progress at the WTO on integrating trade, environment, and sustainable development has been glacial. By default, it has fallen to bilateral and regional free trade agreements (FTAs) to take up the slack.

In the follow-up to the 1992 U.N. Conference on Environment and Development held at Rio de Janeiro (the Rio Earth Summit), the United Nations sponsored an international conference on sustainable development at Johannesburg, South Africa in 2002. ${ }^{1}$ At the conclusion of the 2002 World Summit on Sustainable Development (the WSSD), the participants proposed an ambitious plan of action. Among the many goals of the WSSD identified in its Plan of Implementation, at least three focus on the interrelationship among investment, trade, environment, and sustainable development: (1) "[p]romote mutual supportiveness between the multilateral trading system and the multilateral environmental agreements, consistent with sustainable development

* Professor of Law, Michigan State University College of Law, East Lansing, Michigan. A draft of this article was presented at a February 2008 symposium sponsored by the Indiana University School of Law - Indianapolis entitled, "Assessing the Impact of Existing Bilateral and Multilateral U.S. Trade Agreements and Attempting Policy Recommendations for the Future." I want to thank the symposium participants for their invaluable comments on my paper, especially Gregory Bowman, Mississippi College School of Law; Sungjoon Cho, Chicago-Kent College of Law; Cherie Taylor, South Texas College of Law; Elizabeth Trujillo, Suffolk University Law School; and Eric Dannenmaier, Indiana University School of Law Indianapolis. Any errors or omissions are entirely mine. The author may be contacted at kenne111@law.msu.edu.

1. See generally U.N. Johannesburg World Summit 2002, Johannesburg, S. Afr., Aug. 26-Sept. 4, 2002, Report of the World Summit on Sustainable Development, U.N. Doc. A/CONF.199/20 (2002), available at http://www.un.org/jsummit/html/documents/ documents.html (follow "Report of the World Summit on Sustainable Development" hyperlink). 
goals, in support of the work programme agreed through WTO, while recognizing the importance of maintaining the integrity of both sets of instruments",; (2) "encourage efforts to promote cooperation on trade, environment and sustainable development ... between the secretariats of WTO, UNCTAD [the United Nations Conference on Trade and Development, which assists developing and least-developed countries with integrating into the WTO multilateral trading system], UNDP [the United Nations Development Program, which assists developing countries with issues of governance and poverty reduction], UNEP [the United Nations Environment Program, which assesses global environmental conditions, develops multilateral environmental agreements, and integrates economic development and environmental protection] and other relevant international environmental and development and regional organizations"3; and (3) "strengthen cooperation among UNEP and other United Nations bodies and specialized agencies, the Bretton Woods institutions and WTO, within their mandates. ${ }^{\star 4}$

Measured against these ambitious goals, what has been achieved at the World Trade Organization since the 2002 World Summit on Sustainable Development? Barring some unforeseen breakthrough at the WTO, the lack of any serious discussion about the interface of trade, environment, and sustainable development over the past seven years may mean that no WTO ministerial-level decision will ever be issued on this vitally important subject. The implications for the United States are that bilateral and regional free trade and investment agreements will have to carry more of the load on this score.

At the national level, what efforts has the United States undertaken to make protection of the environment and the promotion of sustainable development a reality in its bilateral free trade agreements? The second half of this paper examines parallel developments in the United States since 2002, in particular the revised environmental and sustainable development provisions that have been recently added to the FTAs negotiated with Colombia, Panama, Peru, and South Korea in 2007, and in the bilateral investment treaty (BIT) entered into with Uruguay in 2006. Briefly, for the first time in the history of the U.S. BIT program, the U.S.-Uruguay BIT includes two provisions that address the interface of investment and environmental protection. The environment and investment chapters of the four most recent FTAs (three of which are still pending congressional approval as of the date of this article) signal a modest departure from the investment and environment chapters of post-NAFTA sister FTAs. Thus, for example, consistent with the North

2. U.N. Johannesburg World Summit 2002, Johannesburg, S. Afr., Plan of Implementation of the World Summit of Sustainable Development, I 92, (Sept. 23, 2002), www.un.org/jsummit/html/documents/undocs.html (follow "Plan of Implementation of the World Summit on Sustainable Development" hyperlink) [hereinafter WSSD Plan of Implementation].

3. Id. ๆ $91(\mathrm{c})$.

4. Id. II 136. 
American Free Trade Agreement (NAFTA), ${ }^{5}$ this set of four FTAs once again gives primacy to an expanded list of seven multilateral environmental agreements (MEAs) (NAFTA listed only three MEAs), so that in the event of an inconsistency between the FTA and the MEAs, the latter will prevail. This return to NAFTA's hierarchy of MEAs over FTA provisions could prove to be a useful means of reinforcing commitments made under the covered MEAs. However, a long-range, integrated package of technical assistance, trade capacity building, and environmental cooperation needs to be initiated by the United States, and the United States needs to be prepared to financially support this package over the ten- to-fifteen-year implementation period of an FTA.

\section{Progress at the WTO SINCE THE WSSD IN Promoting SUSTAINABLE DEVELOPMENT}

In anticipation of the WSSD, the trade ministers of the WTO Members made the following declaration regarding sustainable development at their biennial ministerial conference held in 2001 at Doha, Qatar:

We strongly reaffirm our commitment to the objective of sustainable development, as stated in the Preamble to the Marrakesh Agreement. We are convinced that the aims of upholding and safeguarding an open and non-discriminatory multilateral trading system, and acting for the protection of the environment and the promotion of sustainable development can and must be mutually supportive. We take note of the efforts by Members to conduct national environmental assessments of trade policies on a voluntary basis. We recognize that under WTO rules no country should be prevented from taking measures for the protection of human, animal or plant life or health, or of the environment at the levels it considers appropriate, subject to the requirement that they are not applied in a manner which would constitute a means of arbitrary or unjustifiable discrimination between countries where the same conditions prevail, or a disguised restriction on international trade, and are otherwise in accordance with the provisions of the WTO Agreements. We welcome the WTO's continued cooperation with UNEP and other inter-governmental environmental organizations. We encourage efforts to promote cooperation between the WTO and relevant international environmental and developmental organizations, especially in the lead-up to the World Summit on Sustainable Development to be held in Johannesburg, 
The one sector-specific item on the Doha Round agenda with a clear sustainable development dimension is found in paragraph 28 of the Doha Ministerial Declaration; namely, the reduction of fisheries subsidies that have encouraged over-fishing and fostered depletion of the world's fish stocks. More broadly, under paragraph 31 of the Doha Ministerial Declaration, the WTO Members agreed to negotiations on a set of three interrelated items:

(i) the relationship between existing WTO rules and specific trade obligations set out in multilateral environmental agreements (MEAs). The negotiations shall be limited in scope to the applicability of such existing WTO rules as among parties to the MEA in question. The negotiations shall not prejudice the WTO rights of any Member that is not a party to the MEA in question;

(ii) procedures for regular information exchange between MEA Secretariats and the relevant WTO committees, and the criteria for the granting of observer status;

(iii) the reduction or, as appropriate, elimination of tariff and non-tariff barriers to environmental goods and services. ${ }^{\text {? }}$

In addition to the items identified in paragraph 31 that are the subject of negotiation, paragraph 51 of the Doha Ministerial Declaration directs the WTO Committees on Trade and Development and Trade and Environment "to identify and debate developmental and environmental aspects of the negotiations, in order to help achieve the objective of having sustainable development appropriately reflected." ${ }^{\prime 8}$ Together, paragraphs 31 and 51 of the Doha Ministerial Declaration represent the "environmental package" of the Doha Round negotiations.

In the way of concrete results, very little, if anything, has actually been achieved to date at the WTO on these mandates. The explanation for the lack

6. World Trade Organization, Ministerial Declaration of 14 November 2001, WT/MIN(01)/DEC/1, 41 I.L.M. 746, 746-747 (2002), available at http://www.undocuments.net/doha-md.htm.

7. Id. at 751 .

8. Id. at 754. At the Hong Kong Ministerial Conference held in 2005, trade ministers called upon the membership to intensify the negotiations on all parts of paragraph 31 of the Doha Declaration in order to fulfill the mandate. World Trade Organization, Ministerial Declaration of 18 December 2005, WT/MIN(05)/DEC (2005), available at http://www.wto.org/english/theWTO_e/minist_e/min05_e/final_text_e.pdf. 
of significant progress is that the topic of trade, environment, and sustainable development has taken a backseat at the WTO to the all-consuming negotiations on agricultural trade. Agricultural trade has become the obsessive focus of the Doha Round multilateral trade negotiations that were launched in November 2001, just as they were the central focus of the Uruguay Round that was launched in 1986 and finally concluded in 1994. Almost from its inception, the Doha Round has moved at a snail's pace. After nearly three years of stalemate, the WTO General Council issued a decision in August 2004 that attempted to break the logjam, outlining a work program for the remainder of the negotiations." Included in the General Council's decision was a statement reaffirming " $[\mathrm{m}]$ embers' commitment to progress in all of these areas of the negotiations in line with the Doha mandates."10 This reaffirmation covers the work of the Committee on Trade and Environment. Not surprisingly, the term "sustainable development" is not found in the General Council's 2004 decision, considering that the topic of agricultural subsidies and market access for agricultural products had largely eclipsed all other negotiation issues.

Despite this valiant effort to reinvigorate the stalled Doha Round negotiations, the Doha Round has limped along for another four years. In the meantime, the President's trade promotion authority (formerly known as "fasttrack" authority) expired in July 2007. Without such authority, shepherding any Doha Round agreement through Congress without amendment is a virtual impossibility, thus sounding the death knell of the Doha Round. Hope lingers that if the Doha Round is successfully concluded, Congress might agree to a specific fast-track approval process for any Doha Round multilateral agreement that eventually emerges. Of course, this is piling one huge assumption successful completion of the Doha Round - on top of an even bigger assumption - fast-track approval by a Democrat-controlled Congress. Given the current state of the Doha Round negotiations in Geneva and the political climate in Washington toward international trade, a successful conclusion of the Doha Round and subsequent approval by Congress are both distant goals.

Turning to the Doha Round negotiations at the WTO, what progress has been made within the Committee on Trade and Environment on its paragraph 31 and paragraph 51 Doha Declaration mandates? In a July 2007 status report, the chairman of the Committee on Trade and Environment (CTE) had no progress to report in connection with paragraph 51 of the Doha Ministerial Declaration. ${ }^{11}$ With regard to paragraph 31(i) of the Doha Ministerial

9. See WTO GENERAL COUNCIL, DOHA WORK PROGRAMME WT/L/579 (2004), http://www.wto.org/english/tratop_e/dda_e/ddadraft31jul04_e.pdf.

10. Id. at 3.

11. See Comm. On Trade and Env't, Report by the Chairman, Ambassador Mario Matus, to the Trade Negotiations Committee, TN/TE/17 (July 25, 2007). The Chairman's report was limited to reporting on the progress of the items contained in paragraph 31 of the Doha Ministerial Declaration. See Comm. On Trade and Dev., Developmental Aspects of the Doha Round of Negotiations, Note by the Secretariat, WT/COMTD/W/143/Rev.2, $\mid 2$ (June 27, 2006) 
Declaration on the relationship between the WTO agreements and the specific trade obligations set out in MEAs, the CTE has attempted to develop a common understanding of the negotiating mandate. Various terms contained in the mandate, such as "specific trade obligation" and "multilateral environmental agreement," have been examined by the WTO Members.

On the meaning of the term "multilateral environmental agreement" China offered the following definition: "MEAs are international treaties designed to protect and improve environment, and properly exploit natural resources."12 In China's view, MEAs should have five elements: (1) authoritativeness (MEAs should have been negotiated under the auspices of the United Nations system); (2) universality (an MEA should have a substantial number of contracting parties that account for a majority of WTO Members); (3) openness (the agreement should be open for accession by relevant parties); (4) impact on trade (MEAs should contain explicit trade measures, the implementation of which should have a substantial impact on trade); and (5) effectiveness (an MEA should be in force and open for accession). ${ }^{13}$ To these five elements India has added a sixth: "there must have been effective participation in the negotiations by countries belonging to different geographical regions and by countries at different stages of economic and social development."14

The Committee participants generally agreed that a specific trade obligation (STO) is one that requires an MEA party to take, or refrain from taking, a particular action. Certain obligations in six MEAs have been identified as STOs by several WTO Members: the Convention on International Trade in Endangered Species of Wild Fauna and Flora (CITES), the Montreal Protocol on Substances that Deplete the Ozone Layer, the Basel Convention on the Control of Transboundary Movement of Hazardous Wastes and their Disposal, the Cartegena Protocol on Biosafety to the Convention on Biological Diversity, the Rotterdam Convention on the Prior Informed Consent Procedure for Certain Hazardous Chemicals and Pesticides in International Trade, and the Stockholm Convention on Persistent Organic Pollutants. ${ }^{15}$

(reporting that no progress had been made in the Committee on Trade and Development on the paragraph 51 mandate).

12. Comm. On Trade and Env't, Identification of Multilateral Environmental Agreements (MEAs) and Specific Trade Obligations, Submission by China, TN/TE/W/35/Rev.1, ๆ 3 (July 3, 2003).

13. See id. Malaysia echoed China's views on the elements of an MEA, expressly noting that regional MEAs are not within the scope of the term. See Comm. On Trade and Env't., Paragraph 31(I) of the Doha Ministerial Declaration, Submission by Malaysia, TN/TE/W/29, ๆ 8-9 (Apr. 30, 2003).

14. Comm. On Trade and Dev., Relationship Between Specific Trade Obligations Set Out in MEAs and WTO Rules, Submission by India, TN/TE/W/23, 14 (Feb. 20, 2003).

15. See Comm. On Trade and Env't., Sub-Paragraph 31(I) of the Doha Declaration, Submission by the United States, TN/TE/W/20, I 11 (Feb. 10, 2003); Comm. On Trade and Env't, Proposal for an Outcome on Trade and Environment Concerning Paragraph 31(I) of the Doha Ministerial Declaration, Submission from Australia and Argentina, TN/TE/W/72/Rev.1, ๆ 5 (May 7, 2007). 
Consistent with the WSSD Plan of Implementation, several WTO Members have made proposals relating to governance principles that are aimed at ensuring mutual supportiveness of WTO-MEA regimes. The following summarizes the proposals and principles that have emerged in discussions at the CTE during the course of the Doha Round (no consensus has built around any of these submissions):

- No Hierarchy. MEAs and the WTO legal regime are "bodies of international law of equal standing." 16 Thus, there is no hierarchy between the WTO and MEA legal regimes. ${ }^{17}$

- Deference. MEAs and the WTO have distinct competencies within a "multilateral governance framework. Accordingly, their respective expertise in environmental and trade issues should be exploited." A corollary is that multilateral environmental policy should be made within multilateral environmental fora, not within the WTO, in accordance with each body's respective expertise and mandate. When a WTO dispute settlement panel "examines issues with an environmental content, relating to a particular MEA, the panel should call for and defer . . . to the expertise of the MEA in question." 19

- Dispute Settlement and Choice of Forum. Closely linked to the principle of deference is dispute settlement and choice of forum. As noted by Switzerland, "We should not fall into the pitfall of wanting to deal with issues in the wrong forum, just because it may be more convenient for one or the other reason (like the availability of an effective dispute settlement system). ${ }^{, 20}$ While

16. Comm. On Trade and Env't., Proposal for a Decision of the Ministerial Conference on Trade and Environment, Submission by the European Communities, TN/TE/W/68, ๆ2 (June 30, 2006)[hereinafter Environment]; Comm. on Trade and Env't, The Relationship Between WTO Rules and MEAs, Submission by Switzerland, TN/TE/W/61, 73 (Oct. 10, 2005)[hereinafter Rules Switzerland]. Compare the WTO Members' submissions with NAFTA Article 104, which gives primacy to three MEAs (CITES, the Montreal Protocol, and the Basel Convention) in the event of a conflict between them and any article in NAFTA.

17. In the hierarchy of international law, jus cogens - peremptory norms of international law - always are superior to any other inconsistent international law rule, whether it is conventional law or customary international law. According to the Vienna Convention on the Law of Treaties, jus cogens are norms accepted and recognized by the international community of States as a whole, from which no derogation is permitted. The prohibitions on genocide, torture, slavery, and piracy, for example, are recognized as jus cogens. Neither WTO law nor MEAs have the status of $j u s$ cogens. Second, according to the principle of $j u$ s posterior, newer law takes precedence over older law. This rule only applies if the countries involved in a conflict are parties to the old and new law. Third, according to the rule of lex specialis, more specific law take precedence over more general law. This rule only applies between countries that are both parties to the conflicting rules. See Rules Switzerland, supra note 16, I 2.

18. See Environment, supra note 16, ๆ 2.

19. Id. ๆf 3.

20. Comm. on Trade and Env't, The Relationship Between Existing WTO Rules and Specific Trade Obligations (STOs) Set Out in Multilateral Environmental Agreements (MEAs): A Swiss Perspective on National Experiences and Criteria used in the Negotiation and Implementation of MEAs, Submission of Switzerland, TN/TE/W/58, ๆ 17(c) (July 6, 2005) [hereinafter Rules and STOs]. 
WTO Members have the right to bring disputes to the WTO dispute settlement mechanism, if a dispute arises between WTO Members that are also parties to an MEA over trade measures that they are applying pursuant to the MEA, then arguably they should resolve it through the dispute settlement mechanism available under the MEA. ${ }^{21}$ This suggestion must be balanced, however, against the direction in Article 23 of the WTO Dispute Settlement Understanding that all WTO rules disputes are to be resolved within the WTO. $^{22}$

- Mutual Supportiveness. The principle of mutual supportiveness, identified in paragraph 98 of the WSSD Plan of Implementation, is based on the assumption that the overall objective of both environmental and trade regimes is the same; namely, improvement of the human condition. ${ }^{23}$ Consequently, under WTO rules, no country should be prevented from taking measures for the protection of human, animal, or plant life or health, or of the environment, thus ensuring the level of protection it considers appropriate. Efforts to safeguard the non-discriminatory multilateral trading system must go hand in hand with the commitment to sustainable development. All WTO bodies should "ensure that the interpretation and application of WTO rules takes due account of, and is mutually supportive with, provisions of MEAs." In that connection, treaties should be construed so as not to create a conflict with other rules of international treaty law. Accordingly, WTO rules should be interpreted in a manner that does not conflict with MEA rules, and vice versa. ${ }^{25}$

Unilateral action should be avoided as far as possible. "Unilateral actions, taken without being supported by multilateral mandates, not only counteract multilateral efforts in dealing with multilateral environmental problems, but also damage the multilateral systems established for the purpose of coping with environmental problems in a collaborative way."26

- Transparency. Working hand-in-glove with the principle of mutual supportiveness is transparency. A mechanism for regular information exchange

21. See Environment, supra note 16.

22. See Understanding on Rules and Procedures Governing the Settlement of Disputes, Apr. 15, 1994, Marrakesh Agreement Establishing the World Trade Organization, Annex 2, art. 23.1, Legal Instruments- Results of the Uruguay Round, 33 I.L.M. 1243 (1994) ("When Members seek the redress of a violation of obligations or other nullification or impairment of benefits under the covered agreements or an impediment to the attainment of any objective of the covered agreements, they shall have recourse to, and abide by, the rules and procedures of this Understanding."). In the view of at least one WTO Member, Article 23 is tantamount to an exclusive subject matter jurisdiction provision. See Comm. on Trade and Env't, Comments by the Separate Customs Territory of Taiwan, Penghu, Kinmen and Matsu on the Submission of the European Communities: "The Relationship Between WTO Rules and MEAs in the Context of the Global Governance System, " TN/TE/W/41, ๆ 6 (June 18, 2004) [hereinafter Comments by $S C T]$.

23. See Rules and STOs, supra note 20, ๆ17(b).

24. See Environment, supra note 16, $\llbracket 2$.

25. See Rules Switzerland, supra note 16, 14.

26. See Comments by SCT, supra note $22, \emptyset 4$. 
between the WTO and MEAs has been proposed. ${ }^{27}$ One of the main objectives of information exchange is the promotion of mutual supportiveness of the environmental and trading systems and the promotion of coherence between the two systems. There are numerous benefits in enhancing cooperation between the secretariats of the MEAs and the WTO, including the prevention of conflicts between MEAs and WTO rules. Information exchange at the international level is essential to achieving complementarities between trade and environmental institutions.

\section{NEXT STEPS AT THE WTO}

A successful completion of the Doha Round could have beneficial effects for the environment and sustainable development. Specifically, in the area of agricultural subsidies, domestic and export subsidies by developed countries in particular, by the United States and the EU - have encouraged overproduction of field crops (corn, cotton, wheat, and soybeans, for example). Such overproduction has in turn put pressure on natural resources, including water and arable land. ${ }^{28}$ In addition, this overproduction has caused injury to farmers in developing countries who cannot compete in domestic and international markets with subsidized agricultural products sold by farmers in developed countries in those same markets. ${ }^{29}$ Thus, if the Doha Round is able to secure real reductions in farm subsidies, important gains for sustainable development in the agriculture sector could be achieved.

To enhance policy coordination and coherence in the WTO/MEA field, continued and increased cooperation and information flow between the WTO and MEA secretariats is important. ${ }^{30}$ Close cooperation between these secretariats could also contribute to promoting synergies between trade and environment and ensuring consistency with regard to the competencies of the respective institutions. Lines of communication and increased information flow between the MEA secretariats and the WTO should be strengthened, for example, by institutionalizing exchange sessions, as well as by granting observer status to MEA secretariats as appropriate. ${ }^{31}$ Taking steps toward giving observer status to MEA secretariats will improve the institutional standing of the WTO in the global community by sending a positive signal to

27. See Environment, supra note 16, \2.

28. See, e.g., Comm. on Trade and Env't. and Trade and Dev., Sustainability Impact Assessments, Communications from the European Communities, Annex III, Sustainability Impact Assessment of the WTO Negotiations in the Major Food Crops Sector, WT/COMTD/W/99, WT/CTE/W/208, TN/TE/W/3 (June 3, 2002).

29. See, e.g., Appellate Body Report, United States - Subsidies on Upland Cotton, WT/DS267/AB/R (Mar. 3, 2005).

30. See, e.g., Comm. on Trade and Env't, Contribution of the United States on Paragraph 31(ii) of the Doha Ministerial Declaration, TN/TE/W/5 (June 6, 2002).

31. See, e.g., Comm. on Trade and Env't., The Relationship between WTO Rules and MEAs in the Context of the Global Governance System, Submission of the European Communities, TN/TE/W/39 (Mar. 24, 2004). 
civil society in both developed and developing countries that the trade and environment linkage is receiving close attention at the WTO. Moreover, observer status for relevant MEAs in WTO bodies, as appropriate, can play a positive role in creating clearer appreciation of the mutually supportive role of trade and environmental policies. Not only should requests from MEAs for observer status be considered in this light, but the CTE should also consider extending invitations to appropriate MEA institutions to attend relevant discussions at the CTE. The WSSD reiterated this goal in its Plan of Implementation, stating that "measures should be taken to strengthen sustainable development institutional arrangements at all levels" in order to achieve objectives such as "integration of the economic, social and environmental dimensions of sustainable development in a balanced manner" and "enhancing participation and effective involvement of civil society and other relevant stakeholders ....."32

In the face of, or perhaps in spite of, the lack of solid progress by the two WTO Committees charged with the responsibility of advancing sustainable development on the Doha Round agenda, in early 2007, WTO Director-General Pascal Lamy called for greater attention to sustainable development at the WTO in a speech delivered to the UNEP. ${ }^{33}$ Of course, a necessary but not sufficient condition to whether principles of sustainable development are to find their way into the WTO legal regime is the success of the Doha Round. The ambition with which those negotiations were launched in late 2001 has waned considerably over the past seven years. Today, their focus has narrowed to three topics: trade in agriculture (the reduction of subsidies and tariffs), improved market access for industrial goods, and improved market access for trade in services. Even if the Doha Round negotiations do yield some modest results - which seems doubtful considering that the negotiations are on the brink of total collapse - the absence of any serious discussion about the interface of trade, environment, and sustainable development may mean that no ministerial-level decision at the WTO will be issued on this vitally important subject. The implications for the United States are that bilateral and regional FTAs will have to carry more of the load.

In summary, to ensure mutual supportiveness between the WTO and MEAs, proper policy coordination, cooperation, and information exchange at national and international levels are essential. There are broad benefits to be gained from policy cooperation, not only in ensuring legal consistency, and thereby avoiding potential conflicts, but also in identifying synergies between international trade and environmental policies so that the international community might move closer to achieving its proclaimed overarching

32. WSSD Plan of Implementation, supra note 2, ๆ 121.

33. Pascal Lamy, Dir.-Gen., WTO, Address to the UNEP Global Ministerial Environment Forum: Globalization and the Environment in a Reformed UN: Charting a Sustainable Development Path, (Feb. 5, 2007) (transcript available at http://www.wto.org/english/news_e/ sppl_e/sppl54_e.htm). 
objective of sustainable development. In short, WTO rules should not be interpreted in "clinical isolation" without considering other complementary bodies of international law, including MEAs.

\section{PROGRESS IN THE UNITED STATES IN PROMOTING ENVIRONMENTAL PROTECTION AND SUSTAINABLE DEVELOPMENT IN FTAS SINCE THE WSSD}

In the Trade Act of $2002,{ }^{35}$ the U.S. Congress identified sustainable development as one of the many goals to be achieved in any bilateral, regional, or multilateral trade and investment agreement negotiated by the United States. How well has the United States done in that regard? After a lull of nearly nine years since the United States last concluded an FTA (that being the NAFTA in 1993), the Bush Administration concluded and implemented a series of nine bilateral and regional FTAs beginning in 2001 - all but one since 2004 - with fourteen countries. Bilateral FTAs (the year of the FTA's entry into force is indicated in parentheses) were concluded and implemented with Jordan (2001), Chile (2004), Singapore (2004), Australia (2005), Morocco (2006), Bahrain (2006), Oman (2006), and Peru (2009). The one regional FTA, the Dominican Republic-Central America Free Trade Agreement (DR-CAFTA), was concluded and implemented with one Caribbean and five Central American nations: Costa Rica (2008), the Dominican Republic (2007), El Salvador (2006), Guatemala (2006), Honduras (2006), and Nicaragua (2006). FTAs were concluded with Panama, Colombia, and Korea in 2007 and await congressional approval. FTAs are being negotiated with Malaysia, Thailand, and the United Arab Emirates.

When Congress renewed the President's fast-track negotiating authority in the Trade Act of $2002,{ }^{36}$ it identified the following environmental and sustainable development negotiating objectives to be pursued by the United States:

(1) ensure that trade and environmental policies are mutually supportive and to seek to protect and preserve the environment and enhance the international means of doing so, while optimizing the use of the world's resources;

34. Appellate Body Report, United States - Standards for Reformulated and Conventional Gasoline, If 17, WT/DS2/AB/R, (Apr. 29,1996) ("That direction reflects a measure of recognition that the General Agreement is not to be read in clinical isolation from public international law" (referring to the clarification of WTO provisions in accordance with customary rules of interpretation of public international law, which the Appellate Body has been directed to apply)).

35. Trade Act of 2002, 19 U.S.C. $\S 3802(b)(11)(D-E)$ (2002).

36. See id. 
(2) seek provisions in trade agreements under which parties to those agreements strive to ensure that they do not weaken or reduce the protections afforded in domestic environmental and labor laws as an encouragement for trade;

(3) ensure that a party to a trade agreement with the United States does not fail to effectively enforce its environmental laws, through a sustained or recurring course of action or inaction, in a manner affecting trade between the parties, while recognizing a party's right to exercise discretion with respect to investigatory, prosecutorial, regulatory, and compliance matters and to prioritize allocation of resources for environmental law enforcement;

(4) strengthen the capacity of U.S. trading partners to protect the environment through the promotion of sustainable development;

(5) reduce or eliminate government practices or policies that unduly threaten sustainable development; and

(6) seek market access, through the elimination of tariffs and non-tariff barriers, for U.S. environmental technologies, goods and services. $^{37}$

NAFTA's environmental provisions and its environmental side agreement, the North American Agreement on Environmental Cooperation (NAAEC), ${ }^{38}$ have served as a general baseline for all environmental provisions contained in post-NAFTA FTAs negotiated by the United States. By way of overview, first, all FTAs negotiated by the Bush Administration contain provisions on the interrelationship among trade, investment, and environment that are loosely modeled after the NAAEC. In addition, in a first-of-its-kind provision in any U.S. BIT, the 2006 BIT between the United States and Uruguay included an article on the environment that is modeled after a parallel provision in the environment chapter of DR-CAFTA, as well as a provision on indirect expropriation that is also modeled after a parallel provision in DRCAFTA. Second, all Bush Administration FTAs have been subject to

37. See id. $\S 3802$.

38. See generally North American Agreement on Environmental Cooperation, U.S.-Can.Mex., Sept. 14, 1993, 32 I.L.M. 1480 (1993) [hereinafter NAAEC]. 
environmental review by the Office of the U.S. Trade Representative. Third, four FTAs that were negotiated with Colombia, Panama, Peru, and South Korea in 2007 contain enhanced environmental and sustainable development provisions mandated by the Bipartisan Agreement on Trade Policy that was reached between Congress and the White House in May 2007.

Against this backdrop, the balance of this paper will discuss the developments within the United States since NAFTA regarding making environmental protection and sustainable development an integral part of U.S. FTAs and BITs.

\section{ENVIRONMENTAL REVIEWS OF FTAS}

In 1993, environmental groups filed an action in federal court to compel the U.S. Trade Representative (USTR) to produce an environmental impact statement for NAFTA. ${ }^{39}$ The U.S. Court of Appeals for the D.C. Circuit ruled that because the President's submission of NAFTA to Congress for approval was not "final agency action," the Administrative Procedure Act did not apply and, consequently, an environmental impact statement was not required under the National Environmental Policy Act. ${ }^{40}$

Undaunted by their failure in court, environmental groups pressured the Clinton Administration to subject all proposed FTAs to some type of environmental impact assessment. In 1999, the Clinton Administration obliged by instituting environmental reviews of all FTAs. ${ }^{41}$ The Executive Order states that " $[t]$ rade agreements should contribute to the broader goal of sustainable development," and that "[e]nvironmental reviews are an important tool to help identify potential environmental effects of trade agreements, both positive and negative, and to help facilitate consideration of appropriate responses to those effects whether in the course of negotiations, through other means, or both., ${ }^{, 42}$ The Executive Order and implementing guidelines required an assessment and consideration of the environmental impacts of trade agreements, including

39. See Pub. Citizen v. U. S. Trade Representative, 5 F.3d 549 (D.C. Cir. 1993), cert. denied, 510 U.S. 1041 (1994).

40. Id. at 553 .

41. See Environmental Review of Trade Agreements, Exec. Order No. 13,141, 64 Fed. Reg. 63,169 (Nov. 16, 1999) [hereinafter Environmental Review of Trade Agreements]. See also The Guidelines for Implementation of Exec. Order 13,141, 65 Fed. Reg. 79,442 (Dec. 19, 1999), available at http://www.ustr.gov/environment/environmental.shtml. The USTR and the Council on Environmental Quality jointly oversee implementation of the Order and Guidelines. The USTR, through the Trade Policy Staff Committee, is responsible for conducting the individual reviews. As described in the Guidelines, the focus of this review is on the possible effects in the United States, although transboundary and global effects may be considered as appropriate and prudent. Only one FTA was subject to an environmental review during the Clinton Administration, that being the FTA with Jordan that was negotiated by the Clinton Administration but implemented by the Bush Administration. This is not unlike the history of NAFTA that was negotiated by the elder Bush but shepherded through Congress by Clinton.

42. See Environmental Review of Trade Agreements, supra note 41. 
written reviews of environmentally significant trade agreements. In 2001, the Bush Administration announced that it would continue the Clinton Administration's policy of conducting environmental reviews of trade agreements pursuant to the latter's executive order and implementing guidelines. $^{43}$

The main focus of FTA environmental reviews is the potential environmental impacts of FTAs on the United States. However, reviews include consideration of global and transboundary effects as well. An analysis of the eight U.S. FTA final environmental reviews that have been conducted since 1999 is beyond the scope of this paper. However, the final environmental review of DR-CAFTA, the most hotly contested FTA since NAFTA, reached the following conclusions: ${ }^{44}$

- "[C]hanges in the pattern and magnitude of trade flows attributable to the FTA will not have any significant environmental impacts in the United States." $" 45$

- DR-CAFTA "will not adversely affect the ability of U.S. federal, state, local, or tribal governments to regulate to protect the U.S. environment." ${ }^{46}$

-Within the Dominican Republic and Central American countries that are parties to DR-CAFTA, "net changes in production and trade are expected to be relatively small because exports to the United States from these countries already face low or zero tariffs. Longer term effects, through investment and economic development, are expected to be greater but cannot currently be predicted in terms of timing, type, and environmental implications. ${ }^{, 47}$

- DR-CAFTA "may have indirect effects on the U.S. environment through transboundary transmission of pollutants (air and water), and through effects on habitat for wildlife, including migratory species. The review examined a range of possible impacts, but did not identify any specific, significant consequences for the U.S. environment.",48

-DR-CAFTA "can have positive environmental consequences in Central America and the Dominican Republic by reinforcing efforts to effectively enforce environmental laws, accelerating economic growth and development through trade and investment, and disseminating environmentally beneficial technologies." ${ }^{\text {A9 }}$ potential negative consequence is deforestation and subsequent loss of habitat for migratory birds.

43. See Delegation of Certain Authorities and Assignment of Certain Functions Under the Trade Act of 2002, Exec. Order 13,277, 67 Fed. Reg. 70,305 (Nov. 19, 2002).

44. See Office of the U.S. Trade Representative, Final Environmental Review of the Dominican Republic-Central America-United States Free Trade Agreement - Executive Summary (Feb. 2005), http://www.ustr.gov/assets/Trade_Agreements/Regional/CAFTA asset_upload_file953_7901.pdf (last visited Mar. 11, 2009).

45. Id. at 1 .

46. Id. at 2 .

47. Id.

48. Id.

49. Id. 
- "As a complement to DR-CAFTA, the United States and the FTA partner countries signed a [NAFTA-plus] Environmental Cooperation Agreement that will enhance the positive environmental consequences of the Agreement." 50

Several environmental groups opposed DR-CAFTA and took issue with the USTR's environmental review. ${ }^{51}$ Although their specific concerns with DR-CAFTA were not addressed, some of their concerns were acknowledged and given expression in the Bipartisan Agreement on Trade Policy that was reached between the Bush Administration and Congress in 2007.

\section{The BIPARTISAN AgREEMENT ON TRADE POLICY}

In May 2007, the Democrat-controlled Congress and the Bush Administration brokered a compromise understanding called the Bipartisan Agreement on Trade Policy, ${ }^{52}$ also known as the "New Trade Policy Template." ${ }^{, 53}$ The Bipartisan Agreement calls for enhanced provisions in all future U.S. bilateral and regional FTAs on: (1) intellectual property protection (striking a balance between the rights of drug companies to protect their patents and the needs of developing countries for life-saving drugs); (2) labor rights (requiring that FTA countries adopt the five basic internationally-recognized labor principles of the ILO Declaration on Fundamental Principles and Rights at Work, i.e., freedom of association, the effective recognition of the right to collective bargaining, the elimination of all forms of forced or compulsory labor, the effective abolition of child labor and a prohibition on the worst forms of child labor, and the elimination of discrimination in respect of employment and occupation); (3) investment (ensuring that foreign investors in the United States have no greater rights than U.S. investors); (4) government procurement (requiring that labor rights protections be included in government procurement contracts); (5) port security (guaranteeing that if a country invokes the national security exception with regard to port security, such an invocation cannot be challenged in an FTA dispute settlement proceeding); and (6) environmental protection and sustainable development (discussed next).

Turning to the environmental provisions of the Bipartisan Agreement, the parties to all future FTAs (including those that had already been negotiated with Colombia, Panama, Peru, and South Korea) must adopt, maintain, and

50. Id. at 3 .

51. See Environmentalists' Letter to Congress on CAFTA, Inside U.S. Trade (Feb. 20, 2004).

52. See generally OFFICE OF THE U.S. TRADE REP., BIPARTISAN AGREEMENT ON TRADE POLICY (May 2007), available at http://www.ustr.gov/assets/Document_Library/ Fact_Sheets/2007/asset_upload_file127_11319.pdf [hereinafter, BIPARTISAN AGREEMENT].

53. See Susan C. Schwab, Ämbassador, Office of the U.S. Trade Rep., Statement on U.S. Trade Agenda (May 10, 2007) (transcript available at http:/www.ustr.gov/Document_Library/ Press_Releases/2007/May/Statement_from_Ambassador_Susan_C_Schwab_on_US_trade_ agenda.html). 
implement laws, regulations, and all other measures to comply with the following seven MEAs: (1) the Convention on International Trade in Endangered Species; (2) the Montreal Protocol on Ozone Depleting Substances; (3) the Convention on Marine Pollution; (4) the Inter-American Tropical Tuna Convention; (5) the Ramsar Convention on Wetlands; (6) the International Whaling Convention; and (7) the Convention on Conservation of Antarctic Marine Living Resources. ${ }^{54}$ However, as bold as this requirement may seem at first blush, it contains three significant qualifications that substantially narrow its application. ${ }^{55}$ First, in order to establish a violation of this commitment, the complaining Party must show that the responding Party's failure to fulfill an obligation under one of the covered MEAs has been "through a sustained or recurring course of action or inaction"- language that tracks verbatim the NAAEC's definition of what constitutes a "persistent pattern of failure." Second, the sustained or recurring course of action or inaction must be "in a manner affecting trade or investment between the Parties." In other words, if the violation occurs outside the trade or investment context, then it cannot be the subject of a complaint. Third, an escape clause has been added that excuses non-enforcement in the bona fide exercise of prosecutorial discretion. ${ }^{57}$

Next, in the environment-investment context, the Bipartisan Agreement departs from NAFTA, which provides that the Parties "should not derogate from" environmental laws to attract investment, ${ }^{58}$ and from DR-CAFTA, which provides that "each Party shall strive to ensure that it does not waive or otherwise derogate from" environmental laws to attract investment. ${ }^{59}$ The Bipartisan Agreement amends the non-derogation obligation for environmental laws and the covered MEAs so that NAFTA's "should not" and DR-CAFTA's "shall strive to" now reads "shall not waive" in the new FTAs, with an allowance for waivers permitted under law provided they do not violate the

54. See, e.g., United States-Peru Trade Promotion Agreement, U.S.-Peru, art. 18.2, April 12, 2006, http://www.ustr.gov/Trade_Agreements/Bilateral/Peru_TPA/Final_Texts/Section_ Index.html [hereinafter U.S.-Peru]. Although the treaty is not yet in force, the full text of the Agreement is available at the Internet source. The environmental chapters of the FTAs with Colombia, Panama, and Korea that are pending congressional approval track the environmental chapter of the US-Peru Trade Promotion Agreement almost verbatim. Those pending agreements are available at http://www.ustr.gov/Trade_Agreements/Bilateral/Section Index.html. However, Peru is further obligated to engage in sustainable forestry practices, an obligation which the other three countries have not assumed. See U.S.-Peru, annex 18.3.4.

55. BIPARTISAN AGREEMENT, supra note 52.

56. See U.S.-Peru, supra note 54, art. 18.2 n.1, art. 18.3 .

57. See, e.g., id. at art. 18.3(1)(b)(i), which provides that "where a course of action or inaction reflects a reasonable, articulable, bona fide exercise of such discretion, or results from a reasonable, articulable, bona fide decision regarding the allocation of such resources," then a Party's failure to enforce its environmental laws and the covered MEAs is excused.

58. NAFTA, supra note 5.

59. Dominican Republic-Central America-United States Free Trade Agreement, art. 17.2(2), Aug. 5, 2004, available at http://www.ustr.gov/Trade_Agreements/Bilateral/CAFTA CAFTA-DR_Final_Texts/Section_Index.html [hereinafter DR-CAFTA]. 
covered MEAs. ${ }^{60}$

Third, in a departure from DR-CAFTA where MEAs are not given primacy over the terms of the FTA in the event of a conflict between the two, ${ }^{61}$ the four pending FTAs include an article that roughly parallels NAFTA Article 104, thus creating a legal hierarchy that places MEAs above the FTA in the event of a conflict:

In the event of any inconsistency between a Party's obligations under this Agreement and a covered [multilateral environmental] agreement, the Party shall seek to balance its obligations under both agreements, but this shall not preclude the Party from taking a particular measure to comply with its obligations under the covered agreement, provided that the primary purpose of the measure is not to impose a disguised restriction on trade. ${ }^{62}$

A footnote to this article states that "[f]or greater certainty, paragraph 4 is without prejudice to multilateral environmental agreements other than covered agreements.",63

The final change introduced by the Bipartisan Agreement deals with the resolution of environmental disputes. ${ }^{64}$ The environment chapters of the Colombia, Panama, Peru, and South Korea FTAs are largely imitative of the

60. See, e.g., U.S.-Peru, supra note 54, art. 18.3(2), which provides as follows:

The Parties recognize that it is inappropriate to encourage trade or investment by weakening or reducing the protections afforded in their respective environmental laws. Accordingly, a Party shall not waive or otherwise derogate from, or offer to waive or otherwise derogate from, such laws in a manner that weakens or reduces the protections afforded in those laws in a manner affecting trade or investment between the Parties.

61. See DR-CAFTA supra note 59, art 17.12. This Article, entitled "Relationship to Environmental Agreements," does not create a legal hierarchy between MEAs and DR-CAFTA as does NAFTA Article 104. See NAFTA, supra note 5, art. 104. Instead, it provides as follows:

The Parties recognize that multilateral environmental agreements to which they are all party play an important role in protecting the environment globally and domestically and that their respective implementation of these agreements is critical to achieving the environmental objectives of these agreements. The Parties further recognize that this Chapter ... can contribute to realizing the goals of those agreements. Accordingly, the Parties shall continue to seek means to enhance the mutual supportiveness of multilateral environmental agreements to which they are all party and trade agreements to which they are all party.

This article alludes to the goal in the WSSD Plan of Implementation that MEAs and trade agreements be mutually supportive. It is also consistent with the view expressed by some WTO Members regarding the legal relationship of MEAs and WTO agreements, i.e., that there is no hierarchy.

62. U.S.-Peru, supra note 54, art. 18.13(4) (emphasis added).

63. Id. at art. 18.13.4, n.11.

64. BIPARTISAN AGREEMENT, supra note 52. 
NAAEC. ${ }^{65}$ For example, they establish a citizen submission process, a secretariat to accept such submissions and develop factual records, and an Environmental Affairs Council to oversee the operation of the environment chapter. However, in a departure from NAAEC, disputes that cannot be resolved by the Council are referred to dispute settlement under the general government-to-government dispute settlement panel mechanism that is overseen by the agreement's Free Trade Commission (comprised of the trade ministers of the contracting states). The referral of disputes to the trade dispute panel mechanism rather than to a special environmental dispute panel is required by the Bipartisan Agreement. ${ }^{66}$ The significance of this change is at least threefold: (1) the decision whether to request a Party-to-Party settlement of an environmental dispute now lies with the Parties' trade ministers instead of with the government minister or official responsible for environmental affairs; (2) a single trade minister may request dispute settlement panel resolution of an environmental dispute instead of a majority of the environment ministers voting to do so as is the case under the NAAEC; and (3) if a responding Party loses the dispute and fails to bring its offending measure into compliance, then trade sanctions (not merely fines as is the case under the NAAEC) may be imposed by the prevailing Party. ${ }^{67}$ However, this change as a practical matter probably signifies little or nothing, if the NAFTA experience is any guide. An environmental dispute settlement panel has never been convened under the NAAEC, and there have been only three NAFTA government-to-government trade dispute panels convened during the 15 years that NAFTA has been in force. $^{68}$ Thus, the likelihood of a dispute settlement panel being convened to resolve an environment dispute under the most recent FTAs seems extremely remote. Nevertheless, the importance of having institutional mechanisms in place for airing complaints about a country's environmental enforcement record should not be totally dismissed. As several commentators have observed, the citizen complaint mechanism established under the NAAEC has led to changes in government behavior, even without resort to formal dispute settlement. ${ }^{69}$

65. See, e.g., U.S.-Peru, supra note 54, ch. 18.

66. BIPARTISAN AGREEMENT, supra note 52.

67. See, e.g., U.S.-Peru, supra note 54, art. 18.12(6), ch. 21.

68. See KeVIn C. KenNEDy, International Trade Regulation: Readings, Cases, Notes, AND PROBLEMS 459-461 (2008).

69. See, e.g., Jonathon G. Dorn, NAAEC Citizen Submissions Against Mexico: An Analysis of the Effectiveness of a Participatory Approach to Environmental Law Enforcement, 20 GEO. INT'L ENVTL. L. REV. 129, 129-130 (2007) ("The strength of the NAAEC procedure is its ability to shine a light on a non-compliant party and 'shame' the party into complying with domestic environmental laws. Such 'shaming' is effective at eliciting corrective action by the noncompliant party because it creates public awareness that the party is knowingly engaging in unlawful activities. While the citizen submission procedure under NAAEC is not perfect, it is a viable candidate to serve as the foundation for the next generation of citizen participation-based environmental treaties."); Kal Raustiala, Police Patrols and Fire Alarms in the NAAEC, 26 LOY. L.A. INT'L \& COMP. L. REV. 389, 393 (2004) (arguing that the NAAEC's citizen submission process plays "an important role in promoting treaty implementation, monitoring performance, 
One noteworthy development that is not part of the Bipartisan Agreement itself is the first-ever biodiversity article in a U.S. FTA. The Trade Promotion Agreements with Colombia and Peru exhort the Parties to promote biodiversity and sustainable development in the following terms:

1. The Parties recognize the importance of the conservation and sustainable use of biological diversity and their role in achieving sustainable development.

2. Accordingly, the Parties remain committed to promoting and encouraging the conservation and sustainable use of biological diversity and all its components and levels, including plants, animals, and habitat, and reiterate their commitments in Article 18.1.

3. The Parties recognize the importance of respecting and preserving traditional knowledge and practices of indigenous and other communities that contribute to the conservation and sustainable use of biological diversity.

4. The Parties also recognize the importance of public participation and consultations, as provided by domestic law, on matters concerning the conservation and sustainable use of biological diversity. The Parties may make information publicly available about programs and activities, including cooperative programs, it undertakes related to the conservation and sustainable use of biological diversity. ${ }^{70}$

The term "sustainable use" is defined as "non-consumptive or consumptive use in a sustainable manner," a singularly unhelpful and somewhat tautological

and ensuring that states comply with their treaty obligations."); Gustavo Vega-Cánovas, NAFTA and the Environment, 30 DENV. J. INT'L L. \& POL'Y 55, 61 (2001) ("The NAAEC may have altered political relations between Mexico and the U.S. by providing a framework in which the EPA could more legitimately claim to examine Mexico's international governance. Also at the domestic level, it seems unlikely that the Mexican government would have responded seriously to a petition from Mexican environmental interest groups absent the internationalization of the incident."); Ignacia S. Moreno, James W. Rubin, Russell F. Smith III \& Tseming Yang, Free Trade and the Environment: The NAFTA, the NAAEC, and Implications for the Future, 12 TUL. ENVTL. L.J. 405, 432 (1999) ("In practice, the NAAEC has established a unique mechanism and structure for trilateral cooperation. . . . [I]t has also spurred domestic efforts to strengthen domestic environmental laws and enforcement.").

70. U.S.-Peru, supra note 54, art. 18.11; U.S.-Colombia Trade Promotion Agreement, U.S.Colom., art. 18.11, Nov. 22, 2006, http://www.ustr.gov/Trade_Agreements/Bilateral/Colombia FTA/Section_Index.html [hereinafter U.S.-Colom.].

71. U.S.-Colom., supra note 70, art. 18.11, n.5. 
definition. Although these provisions are obviously hortatory, they nevertheless represent an intriguing innovation in U.S. FTA negotiation and focus.

The four FTAs negotiated in 2007 contain the following clarifying provision in their respective investment chapters: "Except in rare circumstances, non-discriminatory regulatory actions by a Party that are designed and applied to protect legitimate public welfare objectives, such as public health, safety, and the environment, do not constitute indirect expropriations." $" 72$ This provision was first added to the U.S.-Chile FTA ${ }^{73}$ in response to a concern that arbitral tribunals which were resolving NAFTA investment disputes were undermining the ability of host countries to enact and enforce rigorous and non-discriminatory environmental laws. That clarifying provision has now been carried forward.

Finally, in the area of BITs, to date, the United States has concluded forty bilateral investment treaties, all with developing countries. Until 2005, when the United States negotiated a BIT with Uruguay, no U.S. BIT contained any provisions on investment and the environment. In an about face, the UruguayU.S. BIT has added two provisions on investment and environment. First, Article 12 of the Uruguay-U.S. BIT provides as follows:

1. The Parties recognize that it is inappropriate to encourage investment by weakening or reducing the protections afforded in domestic environmental laws. Accordingly, each Party shall strive to ensure that it does not waive or otherwise derogate from, or offer to waive or otherwise derogate from, such laws in a manner that weakens or reduces the protections afforded in those laws as an encouragement for the establishment, acquisition, expansion, or retention of an investment in its territory. If a Party considers that the other Party has offered such an encouragement, it may request consultations with the other Party and the two Parties shall consult with a view to avoiding any such encouragement.

2. Nothing in this Treaty shall be construed to prevent a Party from adopting, maintaining, or enforcing any measure otherwise consistent with this Treaty that it considers appropriate to ensure that investment activity in its territory is

72. U.S.-Peru, supra note 54, annex 10-B, ๆ 3(b).

73. See United States-Chile Free Trade Agreement, U.S.-Chile, annex 10-D, ๆ 4(b), June 6, 2003, http://www.ustr.gov/Trade_Agreements/Bilateral/Chile_FTA/Final_Texts/Section_Index. html ("Except in rare circumstances, nondiscriminatory regulatory actions by a Party that are designed and applied to protect legitimate public welfare objectives, such as public health, safety, and the environment, do not constitute indirect expropriations."). 
undertaken in a manner sensitive to environmental concerns. ${ }^{74}$

While innovative in the history of U.S. BITs, this article is largely precatory. First, the phrase "shall strive to ensure that is does not waive" is the same phrase used in the parallel provision in the DR-CAFTA environment chapter. This phrase has been turned into a mandatory obligation - "shall not waive"in the FTAs concluded in 2007 as a result of the Bipartisan Agreement. Secondly, if there is a violation of this article, the aggrieved Party may only request consultations. In other words, a violation may not be the subject of binding Party-to-Party dispute settlement.

A second provision in the U.S.-Uruguay BIT concerns indirect or "creeping" expropriation. Following investor-host state arbitrations under NAFTA Chapter 11 that appeared to threaten the ability of a host state to enact environmental regulations without also being required to pay compensation to foreign investors for such regulation, beginning with the U.S.-Chile FTA and all other post-NAFTA FTAs, the following clarifying provision has been added:

Except in rare circumstances, non-discriminatory regulatory actions by a Party that are designed and applied to protect legitimate public welfare objectives, such as public health, safety, and the environment, do not constitute indirect expropriations. ${ }^{75}$

The same provision was added verbatim to the U.S.-Uruguay BIT, ${ }^{76}$ the first

74. U.S.-Unuguay Bilateral Investment Treaty, U.S.-Uru., art.12, Nov. 4, 2005, http://www.ustr.gov/Trade_Agreements/BIT/Uruguay/Section_Index.html (follow "Text of the Agreement" hyperlink) (footnote omitted) (emphasis added) [hereinafter U.S.-Uruguay BIT].

75. Id., at annex B, 1 4(b). A handful of U.S. BITs that were concluded after 1994 (the year in which NAFTA went into effect) contain the following preambulary language: "these objectives [to promote greater economic cooperation and investment] can be achieved without relaxing health, safety and environmental measures of general application." See, e.g., Treaty between the United States and the Republic of Georgia Concerning the Encouragement and Reciprocal Protection of Investment, U.S.-Geor., Mar. 4, 1994, S. TREATY DOC. No. 104-13 (1995) (entered into force Aug. 17, 1997); Treaty between the United States and the Republic of Bolivia Concerning the Encouragement and Reciprocal Protection of Investment, U.S.-Bol., Apr. 17, 1998, S. TrEaTY Doc. No. 106-25 (2000) (entered into force June 6, 2001); Treaty between the United States and the Republic of Croatia Concerning the Encouragement and Reciprocal Protection of Investment, U.S.-Croat., July 13, 1996, S. TREATY Doc. No. 106-29 (2000) (entered into force June 20, 2001); Treaty between the United States and the Republic of Azerbaijan Concerning the Encouragement and Reciprocal Protection of Investment, U.S.Azer., Aug. 1, 1997, S. Treaty Doc. No. 106-47 (2000) (entered into force Aug. 2, 2001). However, these BITs do not obligate the contracting states to refrain from derogating from their environmental laws when approving or regulating an investment. Likewise, none of them addresses the issue of indirect expropriation through regulatory measures designed to protect public health, safety, and the environment.

76. See U.S.-Uruguay BIT, supra note 71, annex B, ๆ 4(b). 
provision of its kind in any U.S. BIT.

\section{NEXT STEPS WITHIN THE UNITED STATES}

What should the next steps be within the United States? Arguably needed but clearly missing are: (1) incentives; and (2) a mechanism to measure the progress countries are making toward sustainable development. First, with regard to incentives, the best way to effectuate the hortatory goals described in Article 18.11 of the Peru and Colombia Trade Promotion Agreements on promoting sustainable development and protecting biological diversity is to build incentives that reward higher standards. There are many ways to structure such incentives. Examples include offering accelerated tariff reductions for countries that meet certain goals and making the availability of funds contingent on performance. A creative package of incentives for continually raising environmental and sustainable development standards needs to be developed.

Second, regarding a mechanism to measure progress toward sustainable development, having the trade lever (club?) at a country's disposal can serve as a useful tool (weapon?) to deter (punish?) non-compliance. But, in the long run, it will be more productive to encourage compliance rather than punish and make threats over non-compliance. Future FTAs with developing countries, in particular those with fragile ecosystems and rich biodiversity, should contain provisions on sustainable development action plans with periodic benchmarks to measure their progress, together with fully-funded budgets to support such plans. A monitoring program run by existing regional or international bodies should be established in order to avoid the appearance of "eco-imperialism" by the United States as the sole monitor and evaluator of what constitutes "progress." A long-range, integrated package of technical assistance, trade capacity building, and environmental cooperation needs to be initiated by the United States, and the United States needs to be prepared to financially support this package over the ten-to-fifteen years during which implementation of an FTA will take place. International organizations, other donor countries, and the private sector must also play a role and contribute to this process.

\section{CONCLUSION}

Why should sustainable development and environmental protection be a goal of multilateral trade agreements negotiated at the WTO, and why should the United States pursue that goal not only at the WTO but also in its bilateral trade agreements? The answer to these two questions is a simple but powerful one: to improve the human condition. The principle of mutual supportiveness, identified in paragraph 98 of the WSSD Plan of Implementation, is based on the assumption that the overall objective of both environmental and trade legal 
regimes is the same, namely the improvement of the human condition by protecting human, animal, and plant life and health. ${ }^{77}$

To what extent does the 2007 Bipartisan Agreement advance this goal? Is the Bipartisan Agreement simply a case of old wine in a new bottle? Is it a legal document or a political statement? The environmental chapter of the four FTAs negotiated in 2007 does signal a departure from the environmental chapters of post-NAFTA sister FTAs. Consistent with NAFTA, they again give primacy to seven MEAs in the event of an inconsistency between the FTA and the MEAs. This return to NAFTA Article 104's hierarchy of MEAs over FTA provisions could prove to be a useful tool to reinforce commitments made under the covered MEAs.

In a departure from NAFTA and its progeny, the Bipartisan Agreement bars FTA partners from derogating from their environmental laws and the covered MEAs in order to attract foreign investment. As a result of the Bipartisan Agreement, a citizen submission process has been added to the environment chapters of the four pending FTAs with a nominally more robust dispute settlement process than the one that exists under NAFTA and other U.S. FTAs. The reality, however, is that with the qualifiers that have been placed on the obligation to enforce environmental laws and to observe the terms of the covered MEAs, it seems highly improbable that the improved dispute settlement mechanism mandated by the Bipartisan Agreement will ever be invoked. Given the experience with the environmental dispute settlement mechanism under the NAAEC -- pursuant to which no dispute settlement panel has ever been convened -- any hypothetical threat to convene a dispute settlement panel to hear an environmental complaint under the other U.S. FTAs will ring hollow. Finally, and for the first time, the U.S. FTAs with Colombia and Peru contain specific articles on biodiversity and sustainable development, provisions that were not mandated by the Bipartisan Agreement. In short, assuming that the four pending FTAs receive congressional approval, only time will tell if the modest changes introduced by the Bipartisan Agreement will help the environment and promote sustainable development.

All FTAs negotiated by the United States should ensure that their interpretation and application take account of, and are mutually supportive of, provisions of multilateral agreements on environment and sustainable development. In short, efforts within the United States to safeguard the nondiscriminatory multilateral trading system must go hand-in-hand with the commitment to sustainable development. As the largest trading nation in the world, the United States is uniquely placed to influence the WTO trade, investment, and sustainable development agenda in a positive way, but it cannot do it alone. The United States is a leading advocate for prohibiting harmful fisheries subsidies. It is also committed to safeguarding the integrity of both sets of international obligations at issue - those in the WTO and those in 
MEAs to which the United States is a party. ${ }^{78}$ At the same time, unilateral action should be avoided as far as possible. Unilateral action, taken without being supported by multilateral mandates, not only undercuts multilateral efforts at dealing with multilateral environmental problems, but also damages the multilateral systems established for the purpose of coping with environmental problems in a collaborative way.

78. See Office of the U.S. Trade Rep., Doha DeVelopment Agenda Policy Brief (Dec. 2005), www.ustr.gov/assets/Document_Library/Fact_Sheets/2005/asset_upload_file937_8545. pdf. 